\title{
Dermatobia hominis in a dog imported from Brazil to Romania
}

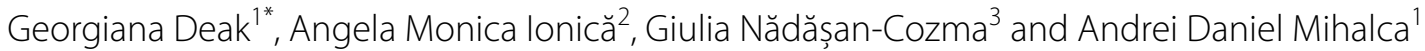

\begin{abstract}
Background: Dermatobia hominis (Diptera: Oestridae: Cuterebrinae) is a parasite with an important zoonotic and economical impact in the cattle industry, distributed in Central and South America, inhabiting wooded areas along rivers and lowlands. It infests mammals including humans. Lately, there has been a growing trend for people to travel on holidays with their pet dog and also international trade of dogs has increased significantly in the last two decades. Hence, the risk of importation of exotic parasites, including agents of myiasis has increased. Dermatobia hominis has been commonly reported as an imported parasite to various countries, mostly as human cases and currently there are only two published cases of $D$. hominis imported with dogs to Europe. Herein, we report a case of D. hominis infestation in Romania in a dog recently imported from Brazil.

Methods: Larvae were manually extracted from nodules of a 4-month old non-neutered male, Fila Brasileiro in Arad, Romania. The larvae were morphologically identified, and one specimen was characterized molecularly by amplification and sequencing of a fragment of the mitochondrial cytochrome c oxidase subunit 1 gene (cox1).

Results: All larvae were morphologically identified as L3 of Dermatobia hominis. The BLAST analysis revealed a 98.81\% nucleotide similarity to two D. hominis isolates from Brazil. The sequence was deposited in the GenBank database under the accession number MT364820.

Conclusions: The travel history of dogs is an important part of the veterinary anamnesis questions and should be thoroughly conducted in the daily practice. Also, prior to and after the importation of dogs from tropical regions, a thorough check of the body surface to detect the presence of nodules is recommended.
\end{abstract}

Keywords: Dermatobia hominis, Imported dog, Romania

\section{Background}

The genus Dermatobia (Oestridae: Cuterebrinae) includes a single species, Dermatobia hominis (Linnaeus, 1781) known as "berne", "torsalo", "the human botfly", "ver macaque", or "tropical warble fly" and affects a wide variety of hosts in the Neotropical region. Its main impact is in the cattle industry and it is also a relevant agent of human myiasis. Other hosts, including dogs are considered accidental. Dermatobia larvae feed on tissues

\footnotetext{
*Correspondence: georgiana.deak@usamvcluj.ro

${ }^{1}$ Department of Parasitology and Parasitic Diseases, University

of Agricultural Sciences and Veterinary Medicine of Cluj-Napoca, Calea Mănăștur 3-5, 400372 Cluj-Napoca, Romania

Full list of author information is available at the end of the article
}

or body liquids and are typically responsible for a diverse range of pathology, but mainly causing cutaneous lesions. They are agents of obligatory myiasis and depend on their host to complete the life cycle, producing furuncular lesions $[1,2]$.

The human botfly is distributed in Central, South and southern North America, inhabiting wooded areas along rivers and lowlands. It typically infests mammals including humans and rarely birds [3-5].

Lately, pet owners travel more and more frequently with their dogs [6, 7]. Moreover, it has been suggested that the international trade with dogs has increased in the last two decades, including dogs from tropical countries [8]. Hence, the risk of importation of exotic

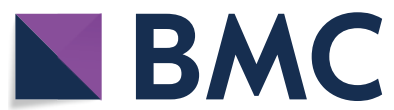

(c) The Author(s) 2020. This article is licensed under a Creative Commons Attribution 4.0 International License, which permits use, sharing, adaptation, distribution and reproduction in any medium or format, as long as you give appropriate credit to the original author(s) and the source, provide a link to the Creative Commons licence, and indicate if changes were made. The images or other third party material in this article are included in the article's Creative Commons licence, unless indicated otherwise in a credit line to the material. If material is not included in the article's Creative Commons licence and your intended use is not permitted by statutory regulation or exceeds the permitted use, you will need to obtain permission directly from the copyright holder. To view a copy of this licence, visit http://creativeco mmons.org/licenses/by/4.0/. The Creative Commons Public Domain Dedication waiver (http://creativecommons.org/publicdomain/ zero/1.0/) applies to the data made available in this article, unless otherwise stated in a credit line to the data. 
parasites, including agent of myiasis is increased. Dermatobia hominis has been commonly reported as an imported parasite to various countries, mostly as human cases [9-11]. However, cases of importation with infested dogs are not so commonly reported. Currently, there are only two published cases of $D$. hominis imported with dogs to Europe, one in France [12] and one in the Netherlands [13]. Here, we report a case of $D$. hominis infestation in Romania in a dog recently imported from Brazil.

\section{Methods}

A 4-months-old non-neutered male, Fila Brasileiro, was referred to a private clinic in the city of Arad, Romania on 22 February 2020 due to the presence of cutaneous nodules on different parts of the body (Fig. 1a). The dog was imported from Brazil (periurban kennel in Itanhandu, State of Minas Gerais) one month before the clinical evaluation. The owner reported a low body score condition (BSC) when the dog arrived in Romania, but it recovered rapidly and was in a good general health. At the time of examination, its appetite and water consumption were normal. Seven days prior to the visit to the clinic, the owner noticed the presence of four nodules: two on the left lateral abdomen, one on the lateral left thigh and one in the interdigital area of the right posterior limb. At that time, the nodules were just small tumefactions of $5-10 \mathrm{~mm}$ in diameter. Initially, the dog was treated at another clinic with amoxicillin and clavulanic acid for several days, without any effect on the nodules. At the time of consultation, the nodules were larger $(1.5-2 \mathrm{~cm})$, well defined, ulcerated, and erythematous, but not painful and without purulent exudate. The regional lymph nodes were not enlarged. Since its importation to Romania the dog had not been administered any antiparasitic drugs, but, according to the owner and the clinical records, in Brazil the dog was treated 5 times with Vetmax ${ }^{\circledR}$ Plus (fenbendazole, pyrantel pamoate and praziquantel) every 21 days, and with a single application of Frontline ${ }^{\circledR}$ (fipronil) before leaving the country. In the same household as the imported dog, there were three other Fila Brasileiro dogs also imported from Brazil (several years before), one Hovawart dog imported from Germany and several European shorthair cats. None of the other animals had any cutaneous nodules.

As there were no signs of pain, the larvae were manually extracted without sedation. Only local treatment with chlorhexidine $4 \%$ (Vetexpert) was applied after extraction. The larvae were stored in absolute ethanol and sent to the Department of Parasitology and Parasitic Diseases (Faculty of Veterinary Medicine Cluj-Napoca) for morphological and molecular identification.

The larvae were identified using the morphological descriptions given by Mathison \& Pritt [14].
One specimen was subjected to genomic DNA isolation, using a commercially available kit (Isolate II Genomic DNA Kit, Bioline, London, UK) and molecularly characterized by amplification and sequencing of a fragment of the mitochondrial cytochrome $c$ oxidase subunit 1 gene $(\operatorname{cox} 1)$, using the universal invertebrate primer pair $\mathrm{LCO} / \mathrm{HCO}$, as previously described [15]. The sequence was compared to those available in GenBank ${ }^{\circledR}$ by Basic Local Alignment Search Tool (BLAST) analysis.

\section{Results}

All larvae were morphologically identified as L3 of $D$. hominis. The larvae were $15-18 \mathrm{~mm}$ long, with an oval/ fusiform shape, but narrower at the posterior extremity (Fig. 1b). Their body presented flower-like anterior spiracles with backward orientated spines that encircled the thorax. The posterior spiracles had three curved slits which were placed in a shallow cavity (Fig. 1c) and the cuticular spines were absent from the last abdominal segments. The anterior extremity had two prominent mouth hooks or buccal maxillae which serve for fixing and feeding on the host (Fig. 1d).

The BLAST analysis revealed a $98.81 \%$ nucleotide similarity to two $D$. hominis isolates from Brazil (GenBank: JQ246701 and AY463155). The sequence was deposited in the GenBank database under the accession number MT364820. The nodules were completely gone after 1 week when the dog was re-checked after the extraction of the larvae.

\section{Discussion}

Dermatobia hominis is a common agent of myiasis of humans and animals in Latin America, but in Europe the cases are sporadic and all of them involve travel history $[12,13,16,17]$. Most of the reports from European countries concern humans who traveled to Central or South America $[18,19]$, and only two cases of $D$. hominis myiasis cases have previously been reported in dogs from Europe [12, 13]. In Romania, D. hominis was reported only once, in 1994, in a 54-year-old female human patient who returned from California [16]. However, as D. hominis is not known from California, this report might either refer to another myiasis (most probably Cuterebra) or the possible site of infection was wrongly identified.

Dermatobia hominis has an interesting life-cycle, as the eggs can be phoretically transported to the body surface of the host by various hematophagous insects (most commonly mosquitoes) where the L1 hatch and actively penetrate the skin. It takes 5-10 weeks until larvae develop to L3, emerge from skin, and drop to the ground to pupate, and afterwards emerge as adults [20]. 

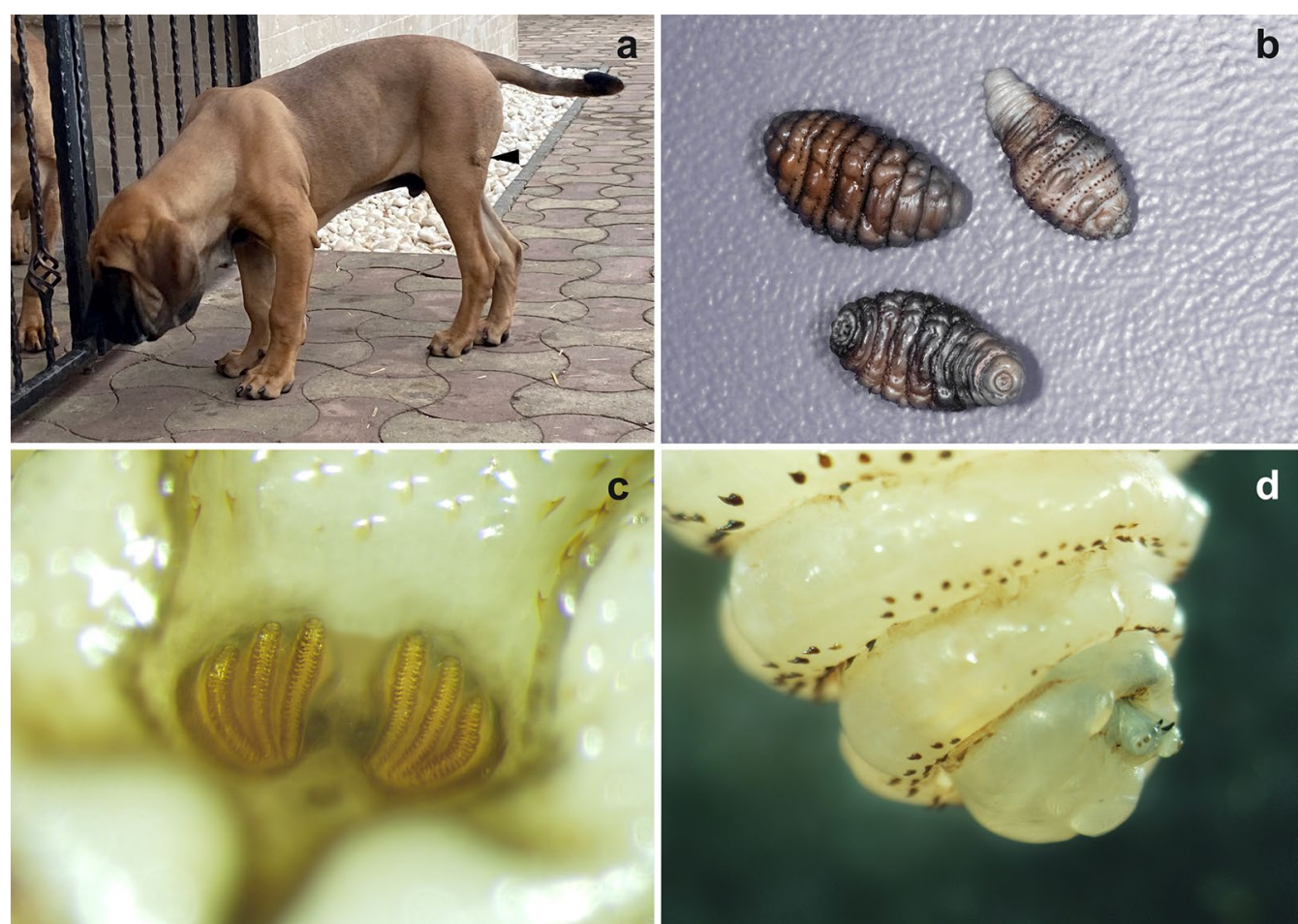

Fig. 1 a A nodule is visible on the lateral side of the thigh (arrowhead). $\mathbf{b}$ Larvae (L2 and L3) of Dermatobia hominis after extraction from the nodules with the typical narrowed posterior extremity. c The typical shape of the spiracles with three curved slits placed in a shallow cavity. $\mathbf{d}$ Anterior extremity of a L2 larva with the presence of buccal maxillae and the posteriorly oriented spines

In humans, the most effective treatment is the surgical removal of larvae from nodules, or their suffocation using occlusive substances to the opening in the nodules through which the larva breathes [21]. Currently, there is no licensed drug for the treatment or prevention of the infestation with Dermatobia in dogs. In humans, oral ivermectin has been successfully used to treat cases where larvae are located in inaccessible regions of the body [22].

\section{Conclusion}

The travel history of dogs is an important part of the veterinary anamnesis questions and should be thoroughly conducted in the daily practice. The travel medicine of pets is an increasingly important field of veterinary medicine. Prior to and after the importation of dogs from tropical regions, to decrease the risk of myiases, we recommend a thorough check of the body surface of dogs to detect the presence of nodules.

\section{Acknowledgements}

Not applicable.

\section{Authors' contributions}

GD performed the morphological identification and wrote the manuscript

AMl performed the molecular biology diagnostic. GNC described the case and collected the samples. ADM coordinated the study and supervised the manuscript preparation. All authors read and approved the final manuscript.

\section{Funding}

Not applicable.

\section{Availability of data and materials}

Data sharing is not applicable to this article as no datasets were generated or analyzed during the present study.

\section{Ethics approval and consent to participate}

The owner consented to publish this case.

\section{Consent for publication}

Not applicable.

\section{Competing interests}

The authors declare that they have no competing interests.

\section{Author details}

${ }^{1}$ Department of Parasitology and Parasitic Diseases, University of Agricultural Sciences and Veterinary Medicine of Cluj-Napoca, Calea Mănăștur 3-5, 400372 Cluj-Napoca, Romania. ${ }^{2}$ Molecular Biology and Veterinary Parasitology Unit (CDS 9), "Regele Mihai I al Romaniei" Life Science Institute, University of Agricultural Sciences and Veterinary Medicine of Cluj-Napoca, Calea Mănăștur 3-5, 400372 Cluj-Napoca, Romania. ${ }^{3}$ Vetpoint Vest Arad Private Clinic, Calea Radnei 113, 310269 Arad, Romania.

Received: 23 April 2020 Accepted: 24 July 2020

Published online: 30 July 2020 


\section{References}

1. Noutsis C, Millikan LE. Myiasis. Dermatol Clin. 1994;12:729-36.

2. Vijay K, Kalapos P, Makkar A, Engbrecht B, Agarwal A. Human botfly (Dermatobia hominis) larva in a child's scalp mimicking osteomyelitis. Emerg Radiol. 2013;20:81-3.

3. Lancaster JL Jr, Meisch MV. Arthropods in livestock and poultry production. New York: Wiley; 1986. p. 402.

4. Shearer D, Wall R. Veterinary entomology: arthropod ectoparasites of veterinary importance. London: Chapman and Hall; 1997. p. 227-9.

5. Russell RC, Otranto D, Wall RL. The encyclopedia of medical and veterinary entomology. Wallingford: CABl; 2013. p. 167-9.

6. Wright I. Parasite prevention in the travelling pet. Companion Animal. 2019;24:175-81.

7. Pet Travel Statistics 2020. https://www.condorferries.co.uk/pet-travel-stati stics. Accessed 15 May 2020.

8. Daugschies A. Importation of parasites by tourism and animal trading, DTW. Dtsch Tierarztl Wochenschr. 2001;108:348-52.

9. Jelinek T, Nothdurft HD, Rieder N, Loscher T. Cutaneous myiasis: a review of 13 cases in travellers returning from tropical countries. Int J Dermatol. 1995:34:624-6.

10. Hohenstein EJ, Buechner SA. Cutaneous myiasis due to Dermatobia hominis. Dermatology. 2004;208:268-70.

11. Calderaro A, Peruzzi S, Gorrini C, Piccolo G, Rossi S, Grignaffini E, et al. Myiasis of the scalp due to Dermatobia hominis in a traveler returning from Brazil. Diagn Microb Infec Dis. 2008;60:417-8.

12. Klap DF, Bourdeau P. Un cas d'infestation par Dermatobia hominis chez le chien en France. Bull Acad Vet France. 1999;72:315-22.

13. Roosje PJ, Hendrikx WM, Wisselink MA, Willemse T. A case of a Dermatobia hominis infection in a dog in the Netherlands. Vet Dermatol. 1992;3:183-5.
14. Mathison BA, Pritt BS. Laboratory identification of arthropod ectoparasites. Clin Microbiol Rev. 2014;1(27):48-67.

15. Folmer $\mathrm{O}$, Black M, Hoeh W, Lutz R, Vrijenhoek R. DNA primers for amplification of mitochondrial cytochrome c oxidase subunit I from diverse metazoan invertebrates. Mol Mar Biol Biot. 1994;3:294-9.

16. Olteanu G, Panaitescu D, Gherman I, Suteu I, Cosoroaba I, Radulescu S, et al. Parazitozoonoze. Probleme la sfarsit de mileniu in Romania. Viata Med Rom Buc. 1999;1:203.

17. Dunphy L, Sood V. Dermatobia hominis 'the human botfly' presenting as a scalp lesion. BMJ Case Reports CP. 2019;1 (12):e228310.

18. Totkova A, Jakubovsky J, Totka A, Bohmer D, Stankovic I, Holeckova K, et al. The first imported human infestation with furuncular myiasis in man in the Slovakia and current knowledge of myiasis. Bratisl Lek Listy. 2016;117:321-7.

19. Di Tullio F, Mandel VD, Miglietta R, Pellacani G. Cutaneous myiasis in a traveler returning from Argentina. Dermatol Ther. 2019;32:e12996.

20. Villalobos G, Vega-Memije ME, Maravilla P, Martinez-Hernandez F. Myiasis caused by Dermatobia hominis: countries with increased risk for travelers going to neotropic areas. Int J Dermatol. 2016;55:1060-8.

21. Smith SM. Treating infestations of the human botfly, Dermatobia hominis. Lancet Infect Dis. 2015;15:512.

22. Wakamatsu TH, Pierre-Filho PT. Ophthalmomyiasis externa caused by Dermatobia hominis: a successful treatment with oral ivermectin. Eye. 2006;20:1088

\section{Publisher's Note}

Springer Nature remains neutral with regard to jurisdictional claims in published maps and institutional affiliations.
Ready to submit your research? Choose BMC and benefit from:

- fast, convenient online submission

- thorough peer review by experienced researchers in your field

- rapid publication on acceptance

- support for research data, including large and complex data types

- gold Open Access which fosters wider collaboration and increased citations

- maximum visibility for your research: over $100 \mathrm{M}$ website views per year

At BMC, research is always in progress.

Learn more biomedcentral.com/submissions 